\title{
Activated eosinophils in adult coeliac disease: evidence for a local release of major basic protein
}

\author{
J F Colombel, G Torpier, A Janin, O Klein, A Cortot, M Capron
}

\begin{abstract}
The eosinophil population is increased in the jejunal mucosa of patients with coeliac disease. Eosinophils may participate in the mucosal damage by releasing their granule components that have cytotoxic properties such as eosinophil cationic protein (ECP) and major basic protein (MBP). This study aimed to assess the presence of ECP and MBP in the jejunal mucosa of 10 adult patients with active coeliac disease who presented with villous flattening. Endoscopic jejunal biopsy specimens were obtained from macroscopically flattened jejunal mucosa and were processed for ultrastructural study and immunogold labelling using anti-MBP, anti-ECP, and antiIgA antibodies. Numerous eosinophils were found in the upper part of the lamina propria and showed two types of morphological change: some were lytic and others exhibited ultrastructural signs of activation, containing altered granules with fading of the central core. IgA plasma cells were intermingled with eosinophils and had dense deposits on the external side of their cytoplasmic membrane. MBP was detected in central cores of granules but also diffusely in their matrix and in tight association with dense extracellular deposits. Conversely, ECP was detected only in the matrix of eosinophil granules. This study showed that numerous eosinophils are in an activated state in the mucosa of patients with active coeliac disease and release cytotoxic proteins such as MBP, which could contribute to the mucosal damage. The observation that eosinophils and IgA plasmocytes were closely associated in the mucosa supports a role for IgA in eosinophil recruitment and activation in coeliac disease.
\end{abstract}

(Gut 1992; 33: 1190-1194)

l'Appareil Digestif Hôpital Claude Huriez, CHU Lille

J F Colombel

O Klein

A Cortot

Service d'Anatomie et

Cytologie Pathologiques,

Hôpital Calmette, CHU

Lille

A Janin

Unité mixte INSERM

U 167-CNRS 624, Institut

Pasteur, Lille, France

G Torpier

M Capron

Correspondence to:

Dr J F Colombel, Clinique des Maladies de l'Appareil

Digestif et de la Nutrition

Hopital Huriez, CHU Lille,

59037, Lille Cedex, France

Accepted for publication

20 December 1991

Eosinophil granulocytes are characterised by their eosin-stained specific granules which contain two compartments that are readily distinguished by their ultrastructure: an inner crystalloid electron dense core and an outer electron radiolucent matrix. ${ }^{1}$ The protein content of the granules is represented by basic proteins: eosinophil cationic protein (ECP), eosinophil-derived neurotoxin (EDN), and eosinophil peroxydase (EPO) are present in the matrix of the granules whereas major basic protein (MBP) is localised in the central core. ${ }^{12}$ These proteins have cytotoxic properties and participate in immunological defence against parasites. $^{13}$ However, the destructive capability of eosinophils may be turned against the host since eosinophil granule proteins may be cytotoxic to a variety of mammalian cells. ${ }^{13-8}$ Eosinophils in the mucosa of the small intestine may protect against bacteria and other agents penetrating the epithelium, but, as suggested for other organs, the cytotoxic potential of eosinophils may also be turned against the digestive tract. Evidence that MBP has a role in tissue damage has been shown in eosinophilic gastroenteritis ${ }^{9}$ and Crohn's disease. ${ }^{10}$

In coeliac disease, much research has emphasised the role of lymphocytes and plasma cells in the pathogenesis of intestinal lesions but other inflammatory cells may also be involved. ${ }^{112}$ Morphometric studies have established that the eosinophil population is expanded appreciably in the coeliac mucosa and returns towards normal during gluten restriction. ${ }^{13-15}$ Extracellular release and tissue deposition of ECP have been shown in the lamina propria of the jejunal mucosa of patients with active coeliac disease. ${ }^{16}$ Using a jejunal perfusion technique, we found that the secretion rate of ECP was eight times greater on average compared with control values. ${ }^{16}$ The mechanism of eosinophil infiltration in coeliac disease is unsolved. Interestingly, Lavö et al showed that the jejunal secretion rate of ECP was increased fourfold in patients with coeliac disease after gliadin challenge. ${ }^{17}$ However, the mechanism by which gliadin challenge might recruit eosinophils or induce the release of their granule constituents remains undetermined. One of the characteristic features of coeliac disease is a massive stimulation of $B$ cells. Immunohistochemical studies and cultures of mucosal small bowel biopsy specimens have indicated enhanced local synthesis of $\operatorname{IgA}$, IgM, and IgG directed specifically against gluten antigens. ${ }^{112}$ Local eosinophil activation and the enhanced mucosal immune response may reflect independently the activity of coeliac disease. Alternatively, a causal relationship may exist eosinophils express $\operatorname{IgA}$ receptors $^{18}$ and may react to IgA containing immune complexes by releasing their granule proteins. ${ }^{18-20}$

In this study, we report ultrastructural

data that further support the involvement of eosinophils in the pathogenesis of lesions in coeliac disease. Using specific antibodies, we assessed the local release of eosinophil proteins in the jejunal mucosa. We also argue in support of the participation of $\operatorname{IgA}$ in eosinophil activation by examining the structural relationship between eosinophils and IgA containing plasmocytes in the jejunal mucosa of patients with coeliac disease.

\section{Methods}


age 33 years, range 16-59) with coeliac disease were studied. At the time of the study they had active disease - that is, symptoms and subtotal villous flattening of the jejunal mucosa. The prominent cellular infiltrate of the lamina propria was dominated by lymphocytes and eosinophils. Three patients were taking a gluten free diet at the time of the study but had a bad clinical and histological response due to failure to comply with the diet. Seven patients were newly diagnosed and all had a subsequent symptomatic and histological response to gluten free diet. At that time only scattered eosinophils were present in the mucosa.
METHODS

Endoscopic biopsy specimens were obtained from macroscopically flat duodeno-jejunal mucosa. Samples were immediately fixed in $1 \%$ glutaraldehyde in cacodylate buffer for one hour at $4^{\circ} \mathrm{C}$. After dehydration, half of the specimens were embedded in Epon and further processed for electron microscopy. The other samples were embedded at $-35^{\circ} \mathrm{C}$ in Lowicryl $\mathrm{K} 4 \mathrm{M}$ medium following the standard procedure of Roth et al..$^{21}$ Sections were floated on a solution of $0.5 \%$ (wt/ vol) ovalbumin in Tris-HCl-buffered saline (20 mM Tris- $\mathrm{HCl}, 0.5 \mathrm{M} \mathrm{NaCl}, \mathrm{pH} 7.4$ TBS) supplemented with $1 \%$ heat inactivated normal
Figure 1: Ultrastructural features of eosinophil and plasma cells in lamina propria of jejunal specimens. (A) Shows one lytic eosinophil (Eo) with altered granules both within the degenerating cytoplasm (arrow) and extracellular space (curved arrow). Some free granules (arrowheads) are aggregated with necrotic material from an altered plasma cell $(P c)$ surrounded by three other intact plasma cells (1 to 3). (B) High magnification of altered granules with an electron lucent central core within an apparently intact eosinophil. (C) Shows dense deposit on a plasma cell surface membrane (arrows) and also on rough

endoplasmic reticulum $(E R)$ membrane from lysed plasma cells.
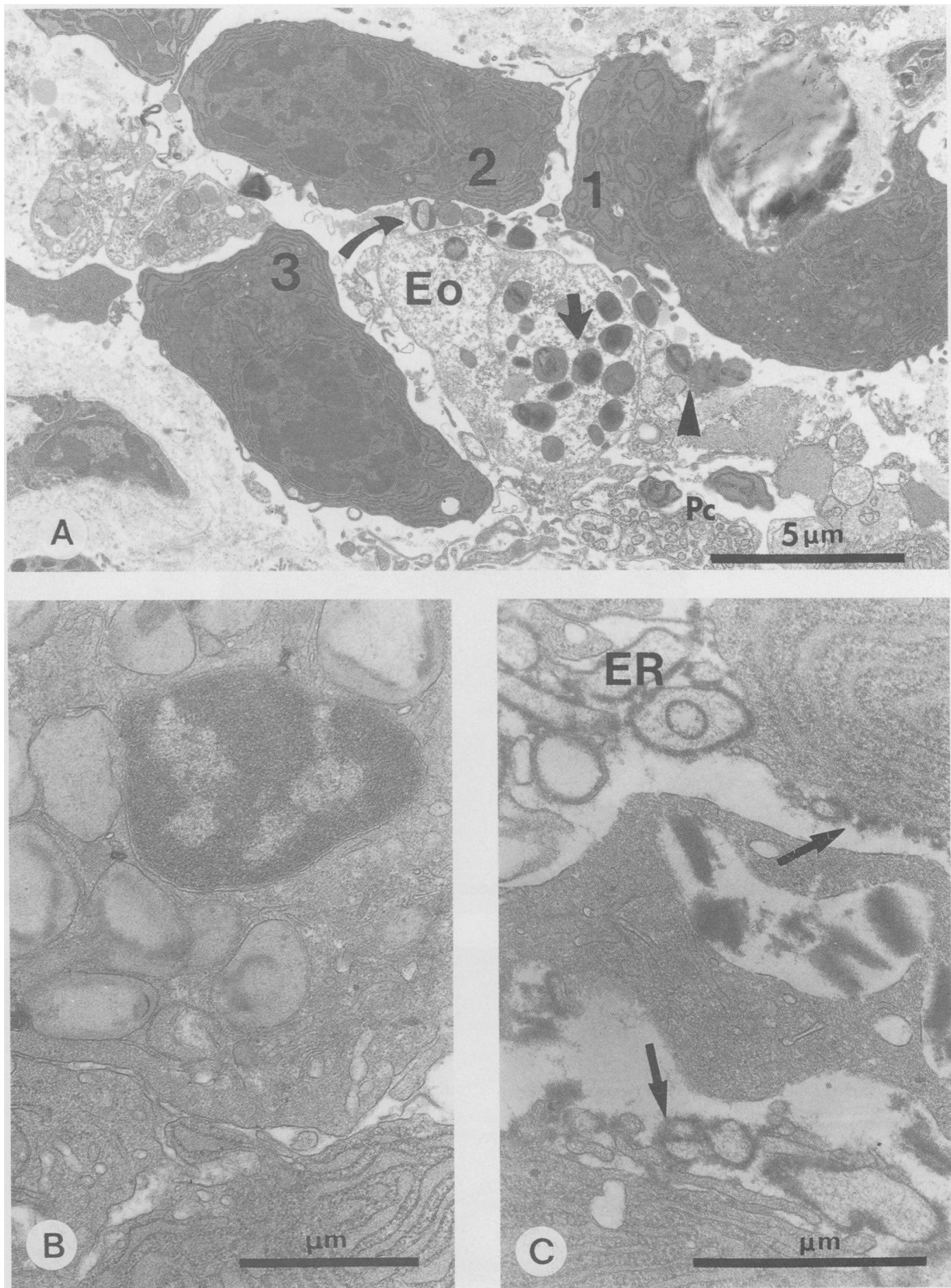
goat serum. This was followed by incubation with the tested antibodies diluted in TBS containing ovalbumin (TBS-OVA) for two hours at room temperature and then washed with TBSOVA. Sections were transferred to drops of the appropriate $10 \mathrm{~nm}$ gold-conjugated goat antiIgG solution (diluted $1 / 30$ to $1 / 40$ ) (Janssen Pharmaceutica, Beerse, Belgium). After $1 \mathrm{~h}$ incubation at room temperature grids were washed with TBS and distilled water successively. Finally, sections were jet washed with distilled water and air dried. Lowicryl sections were stained with uranyl acetate and lead citrate. Observations were made at $80 \mathrm{~kW}$ with a Philips EM 420 electron microscope.

Affinity purified rabbit antiserum to $\mathrm{MBP}$ (kindly provided by Dr G J Gleich, Rochester, Minnesota), mouse monoclonal antibody to the activated form of ECP (EG2, kindly provided by Dr Po-Chun-Tai, London, UK), and anti-IgA antibody (Behring) were used as the primary reagents. Auroprobe goat anti-rabbit and antimouse IgG (Janssen) were used as the secondary reagents. The specificity of the immunostaining was tested by (a) omitting the first antibody and; (b) substituting the specific antibodies with the preimmune serum or with unrelated (antiglutathione S-transferase) antibodies whose labelling pattern had been previously analysed."2 No immunoreactivity was observed on control sections.

\section{Results}

ULTRASTRUCTURAL ANALYSIS OF EOSINOPHILS

Tissue sections of jejunal mucosa biopsy specimens were analysed by electron microscopy. Similar results were observed in the 10 patients. Eosinophils were numerous and mostly localised in the upper part of the lamina propria, a few were scattered within the basal layer of the atrophic epithelium. In the superficial part of the lamina propria, eosinophils were intermingled with numerous plasma cells with well developed rough endoplasmic reticulum (Fig 1A). More than $90 \%$ of eosinophils showed morphological changes. There were two types of change: $25 \%(18-31)$ of eosinophils were lytic with no nucleus and desegregation of the cytoplasm. They were surrounded by free granules with altered central cores (Fig 1A). Seventy five per cent (69-82) of eosinophils had an intact nucleus and cytoplasm but contained altered granules with an almost complete fading of the central core (Fig 1B). This kind of ultrastructural
Figure 2: Immunogold staining on ultrathin sections of Lowicryl K4M embedded jejunal specimens. (A) Major basic protein is present in central core of altered eosinophil free granules (arrows) and is also associated with dense extracellular material (arrowheads). (B)

Eosinophil cationic protein is exclusively found in the matrix of free altered granules (arrow) and not on dense extracellular material. (C) Shows immunogold labelling of IgA within plasma cell rough endoplasmic reticulum. (D) Shows IgA located in extracellular aggregates (arrow) close to altered free eosinophilic granule (arrowhead).

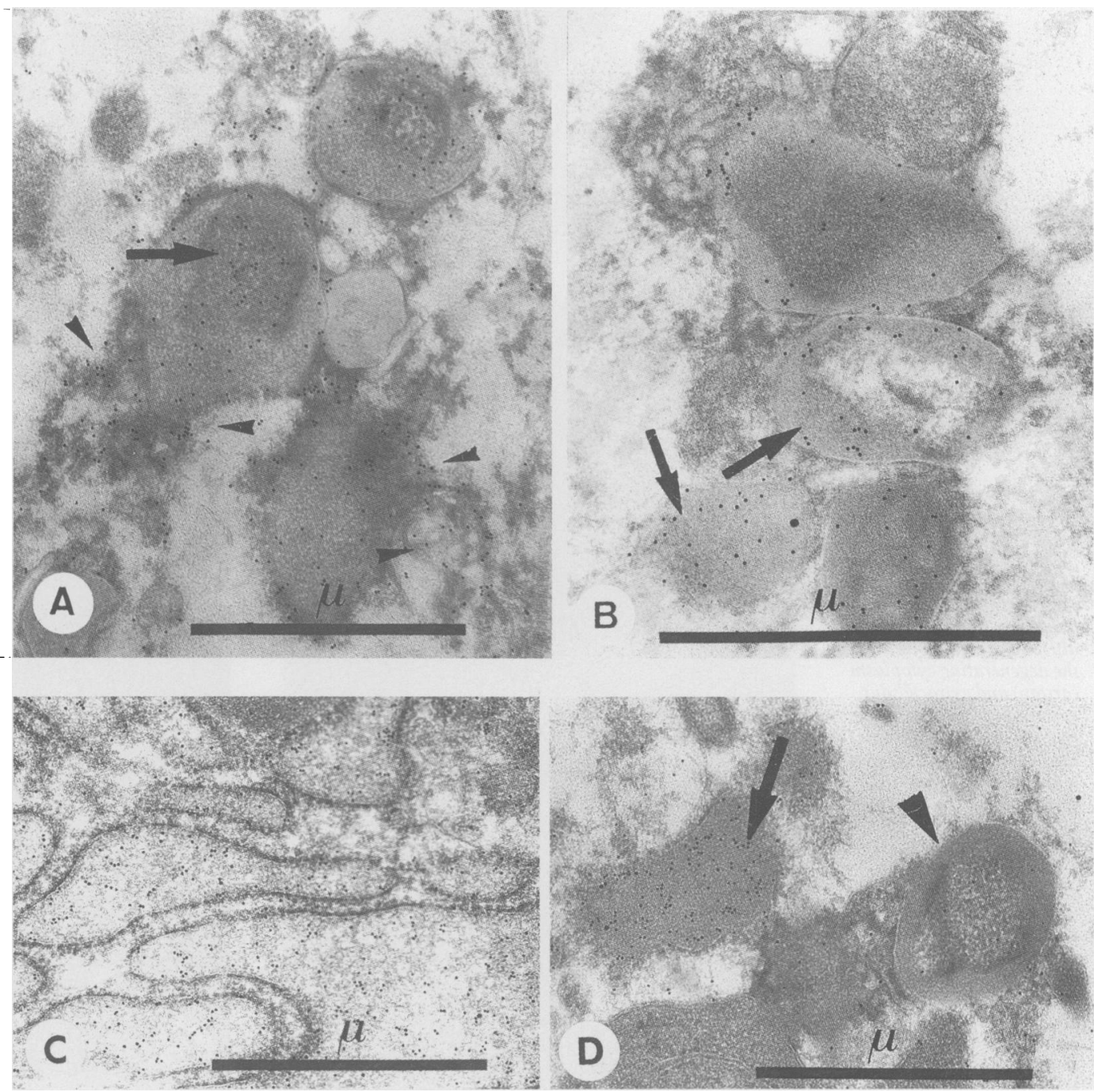


change affected either all the granules or some of them. At a higher magnification, plasma cells located around lytic eosinophils had dense deposits on the external side of their cytoplasmic membrane. Similar deposits were also observed on the rough endoplasmic reticulum membrane of lysed plasma cells (Fig 1C). Thus, this ultrastructural analysis confirmed the presence of numerous altered eosinophils and suggested the deposition of dense extracellular material in close contact with plasma cells.

\section{IMMUNOSTAINING OF EOSINOPHIL PROTEINS}

To identify the components of these deposits, immunostaining with anti-MBP, anti-ECP, and anti-IgA antibodies was performed. On sections stained with anti-MBP antibody, gold particles were found on central cores of intact granules and on remnants of central cores of altered granules. MBP was also detected diffusely in the matrix of altered granules and in tight association with dense extracellular deposits (Fig 2A). In contrast, immunogold labelling with EG2 antibody showed that ECP was normally present in the matrix of all eosinophil granules as well as in the matrix of free altered granules but was not detected in the dense extracellular material (Fig 2B). These findings were present in all the 10 biopsy specimens examined. On sections stained with anti-IgA antibody, numerous gold particles were found within plasma cell endoplasmic reticulum (Fig 2C) and also, in 8 of 10 patients, in extracellular aggregates close to altered free eosinophil granules (Fig 2D).

\section{Discussion}

In the 10 adult patients with coeliac disease who had total or subtotal villous flattening, eosinophils were numerous in the jejunal mucosa and showed appreciable structural alterationssome were lytic with release of partly altered granules, and some showed a less extreme change with disappearance of granule central cores. The presence of eosinophils with these changes in areas just beneath the surface epithelium of the flattened villi may suggest their participation in the mucosal damage of coeliac disease. Firstly, toxic cationic proteins may be released from the lytic eosinophils. ${ }^{2}$ Furthermore, eosinophils are able to release their cytotoxic products without being lytic. ${ }^{1-3}$ Previous studies of eosinophils from the blood and tissues of patients with eosinophil-related diseases have suggested that morphological changes may be associated with an activated state and degranulation..$^{1-3}$ In particular, fading of the central core of eosinophil granules, detected in numerous eosinophils present in the jejunal mucosa of patients with coeliac disease, may be linked with MBP release as shown in other inflammatory bowel diseases such as Crohn's disease $^{10}$ or eosinophilic gastroenteritis. ${ }^{9}$

The mechanism by which activated eosinophils damage jejunal mucosa in coeliac disease remains uncertain. However, evidence focuses on cationic proteins, which are the most damaging to the host..$^{1-8}$ Immunogold labelling with specific antibodies allowed us to assess the presence of MBP and ECP released from altered granules in the jejunal mucosa of patients with coeliac disease. The diffuse presence of MBP and its tight association with dense extracellular material suggest that it can bind target cell membranes causing direct damage to jejunal mucosa. Accordingly, guinea pig MBP has been shown to be toxic to intestinal cells' whereas a selective release of MBP was shown in the ulcerated areas of a patient with eosinophilic gastroenteritis. ${ }^{9}$ A similar phenomenon has been proposed for tissue lesions in patients with Crohn's disease. ${ }^{10}$ Immunolabelling of ECP, which is normally present in the matrix of eosinophil granules, ' 2 showed that it was also present in coeliac disease but not reassociated with surrounding structures. ECP as well as MBP can exert a potent cytotoxic activity in vitro $^{13}$ and large amounts of ECP have previously been demonstrated with immunoperoxidase on paraffin sections in the lamina propria infiltrated with eosinophils of patients with coeliac disease. ${ }^{16}$

The mechanism of eosinophil activation in coeliac disease is unknown. Jejunal crypt hyperplasia and later villous flattening develop subsequent to the gluten induced increase in intraepithelial lymphocytes (IEL). ${ }^{23}$ In IEL, particular attention has been paid to the $\gamma / \delta+$ IEL subset, which is increased in small intestinal biopsy specimens of patients with untreated coeliac disease. ${ }^{2+25}$ However, the functional properties of human IEL are so far not clear. Activated mucosal $\mathrm{T}$ cells may also play a role in the pathogenesis of coeliac disease through the generation of various cytokines. ${ }^{126} \mathrm{~A}$ number of endogenous factors, in particular interleukin 5 release from stimulated lymphocytes, seem to have considerable potential to augment several of the effector properties of eosinophils. ${ }^{27}$ This link between the activation of lymphocytes and eosinophils may partly explain the mucosal accumulation of eosinophils in coeliac disease. Another characteristic feature in the mucosa of untreated coeliac disease is the appreciable increase in plasma cells in the lamina propria. 112 Enhanced intestinal secretion of antibodies with specificity for gliadin and to a lesser extent for other food antigens has been shown in coeliac disease. ${ }^{29-31}$ We have shown an increased jejunal secretion rate of secretory $\operatorname{Ig} A$ and $\operatorname{Ig} M$ in patients with coeliac disease as well as the presence of polymeric antigliadin-IgA linked to secretory component in the jejunal lumen. ${ }^{32}$ Receptors for IgA have recently been reported on human eosinophils ${ }^{18}$ and IgA is one of the most potent signals for eosinophil degranulation. ${ }^{19} 20$ Thus, the formation of gliadin-IgA complexes may theoretically contribute to degranulation of eosinophils in the mucosa, provided that the complexes become adhered to the cells. The structural association between eosinophils and IgA secreting plasma cells in the atrophic coeliac mucosa and the concomitant presence of MBP and $\operatorname{IgA}$ within extracellular deposits might reinforce this hypothesis. Further work is needed to determine the relative contribution of cytokines such as interleukin 5 and of immunoglobulins to eosinophil recruitment and activation in coeliac disease. 


\section{Addendum}

Since this paper was accepted for publication, we have shown that eosinophils infiltrating the mucosa of patients with active coeliac disease express the IL-5 m RNA. Thus, in coeliac disease, eosinophils could contribute to paracrine interactions with $\mathrm{T}$ an $B$ cells and, in autocrine fashion, participate in local eosinoph activation (Desreumaux P, Janin A, Colombel JF, Prin L, Pluma $\mathrm{J}$, Emilie D, et al. F Exp Med 1992; 175: 293-6).

1 Gleich JG, Adolphson CR. The eosinophil leukocyte: structure and function. Adv Immunol 1986; 39: 177-233.

2 Dvorak AM, Ackerman SJ, Weller PF. Subcellular morphology and biochemistry of eosinophils. In: Harris JR, ed
Blood cell biochemistry. Vol 2. London: Plenum Publishing, Blood cel 1991 .

3 Weller PF. The immunobiology of eosinophils. N Englf $\mathrm{Med}$ 1991; 324: 1110-9.

4 Gleich GJ, Frigas E, Loegering DA, Wassom DC, Steinmuller D. Cytotoxic properties of the eosinophil major basic protein. F Immunol 1979; 123: 2925-7.

5 Durack DT, Ackerman SJ, Loegering DA, Gleich GJ Purification of eosinophil derived neurotoxin. Proc Nat Acad Sci USA 1981; 78: 5165-9.

6 Fredens K, Dahl R, Venge P. The Gordon phenomen induced by eosinophil cationic protein and eosinophil protein X. F Allergy Clin Immunol 1982; 70: 361-6.

7 Ayars GH, Altman LC, Gleich GJ, Leogering DA, Baher CB. Eosinophil and eosinophil granule-mediated pneumocyte injury. F Allergy Clin Immunol 1985; 75: 595-604.

8 Shah AM, Brutsaert DL, Meulemans AL, Andries LJ, Capron $M$. Eosinophils from hypereosinophilic patients damag endocardium of isolated feline heart muscle preparations. Circulation 1990; 81: 1081-8.

9 Torier G, Colombel JF, Mathieu-Chandelier C, Capron M, Dessaint JP, Cortot A, et al. Eosinophilic gastroenteritis: ultrastructural evidence for a selective release of eosinophil major basic protein. Clin Exp Immunol 1988; 74: 404-8.

10 Dvorak AM. Ultrastructural evidence for release of major basic protein-containing crystalline cores of eosinophil granules in vitro: cytotoxic potential in Crohn's disease. granules in vitro: cytotoxic

11 Strober W. Gluten sensitive enteropathy, an abnormal immunologic response of the gastrointestinal tract to a dietary protein. In: Shorter RG, Kirsner JB, eds. Gastrointestinal immunity for the clinician. Orlando: Grune and Stratton, 1985: 75-112.

12 Brandtzaeg P. Immunologic basis for celiac disease, inflammatory bowel disease, and type B chronic gastritis. Cur Opin Gastroenterol 1991; 7: 450-62.

13 Modigliani R, Matuchansky C, Galian A, Poupon R Rambaud JC, Bernier JJ. Maladie coeliaque de l'adulte. I. Etude anatomoclinique, biologique et radiologique; évolution sous régime sans gluten. Gastroenterol Clin Biol 1975; 64: 465-81.

14 Marsh MN, Hinde J. Inflammatory component of coeliac sprue mucosa. I. Mast cells, basophils and eosinophils. Gastroenterology 1985; 89: 92-101.

15 Anand BS, Piris J, Jerrome DW, Offord RE, Truelove SC. The timing of histological damage following a single challenge with gluten in treated coeliac disease. $Q \mathcal{F}$ Med 1981; 197: 83-94.

16 Hällgren R, Colombel JF, Dahl R, Fredens K, Kruse A, Jacobson NO, et al. Neutrophil and eosinophil involvement of the small bowel in patients with celiac disease and Crohn's disease: studies on the secretion rate and immunohistochemical localization of granulocyte granule constituents. Am 7 Med 1989; 86: 56-64.

17 Lavö B, Knutson L, Loof L, Odlind B, Venge P, Hällgren R. Challenge with gliadin induces eosinophil and mast cel activation in the jejunum of patients with celiac disease. Am $\mathcal{F}$ Med 1989; 87: 655-60.

18 Capron M, Tomassini M, Van Der Vorst E, Kusnierz JP Papin JP, Capron A. Existence et fonctions d'un récepteur pour l'immunoglobuline $\mathrm{A}$ sur les éosinophiles humains. C R Acad Sci Paris 1988; 307: 397-402.

19 Abu-Ghazaleh RI, Fujisawa T, Mestecky J, Kyle RA, Gleich GJ. IgA-induced eosinophil degranulation. F Immunol 1989; 142: 2393-400.

20 Tomassini M Tsicopoulos A, Tai PC, Gruart V, Tonnel AB Prin $\mathrm{L}$, et al. Release of granule proteins by eosinophils from allergic patrients with eosinophilia upon immunoglobulin dependent activation. F Allergy Clin Immunol 1991; 88: 365-75.

21 Roth J, Bendayan M, Carlemalm E, Villinger W, Garavito M Enhancement of structural preservation and immunocytochemical staining in low temperature embedded pancreatic tissue. F Histochem Cytochem 1981; 29: 663-71.

22 Taylor JB, Vidal A, Torpier G, Meyer DJ, Roitch C, Balloul $\mathrm{JM}$, et al. The glutathione transferase activity and tissue distribution of a cloned $\mathrm{Mr} 28 \mathrm{~K}$ protective antigen of distribution of a cloned $\mathrm{Mr} 28 \mathrm{~K}$ protective

23 Marsh MN. Morphology and immunopathology of the jejunal lesions in gluten-sensitivity. Eur $\mathcal{F}$ Gastroenterol Hepatol 1991; 3: 108-14.

24 Spencer J, Isaacson PG, Diss TC, MacDonald TT. Expression of disulfide-linked and non-disulfide-linked forms of the T cell receptor $\gamma / \delta$ heterodimer in human intestinal intraepithelial lymphocytes. Eur F Immunol 1989; 19: 1335-8.

25 Halstensen TS, Scott S, Brandtzaeg P. Intraepithelial T cell of the $\mathrm{TCR} \gamma / \mathrm{\delta}+\mathrm{CD} 8-$ and $\mathrm{V} / \mathrm{l} / \mathrm{\delta l}+$ phenotypes are increased in coeliac disease. Scand 7 Immunol 1989; 30 $665-72$.

26 MacDonald TT, Spencer J. Evidence that activated mucosa $T$ cells play a role in the pathogenesis of enteropathy in human small intestine. $\mathcal{F}$ Exp Med 1988; 167: 1341-9.

27 Lopez AF, Sanderson CJ, Gamble JR, Campbell HD, Young IG, Vadas MA. Recombinant human interleukin 5 is selective activator of human esinophil function. $\mathcal{F} \mathrm{Exp} M \mathrm{Med}$ 1988; 167: 219-24.

28 Yamaguchi Y, Hayashi Y, Sugama Y, Miura Y. Highly purified murine interleukin 5 (IL-5) stimulates eosinophi function and prolongs in vitro survival. $\mathcal{J} \operatorname{Exp}$ Med 1988 167: $1737-42$.

29 Wood GM, Howdle PD, Trejdosiewicz LK, Losowsky MS. Jejunal plasma cells and in vitro immunoglobulin production in adult coeliac disease. Clin Exp Immunol 1987; 69: 123-32.

30 Crabtree JE, Heatley RW, Losowsky ML. Immunoglobulin secretion by isolated intestinal lymphocytes: spontaneous production and $T$-cell regulation in normal small intestin and in patients with coeliac disease. Gut 1989; 30: 347 54.

31 Ciclitra PJ, Ellis HJ, Wood GM, Howdle PD, Losowsky MS Secretion of gliadin antibody by coeliac jejunal biopsie cultured in vitro. Clin Exp Immunol 1986; 64: 119-24.

32 Colombel JF, Mascart-Lemone F, Nemeth J, Vaerman JP, Dive C, Rambaud JC. Jejunal immunoglobulin and antigliadin antibody secretion in adult coeliac disease. Gut 1990 31: 1345-9. 